\title{
SENSITIVITY ANALYSIS OF CORE DEPOSITORS: A COMPARISON BETWEEN ISLAMIC AND CONVENTIONAL BANKS IN INDONESIA
}

\author{
Saidah Nia*, Achsani Noer Azam \\ School of Business, Bogor Agricultural University, Bogor, Indonesia \\ Ismal Rifki \\ Bank Indonesia (The Central Bank of Indonesia), Jakarta, Indonesia \\ *E-mail: niasaidah89@gmail.com
}

\begin{abstract}
Islamic banking grows promisingly in line with an increase in public confidence in Islamic business and the economy. Even though there is an increase in terms of assets, financing, and deposits, there has been a slowdown in business growth in the last five years, due to (i) the high cost of funds, (ii) low public understanding and awareness so that Islamic bank depositors are only dominated by certain group or categories commonly called core depositors, and (iii) the behaviors of core depositors which tend to carry out displaced commercial risk, and may withdraw funds or disbursement of deposits at any time. Besides, the problem of core depositors' behaviors could also cause liquidity imbalance in banks which is dominated by short-term funding with longer-term financing tenors. These conditions must be the focus of banks to mitigate liquidity risks to increase profitability and business performance. This study aims to analyze the internal and macroeconomic factors that affect the sensitivity of core depositors in Islamic and conventional banking in Indonesia used the Autoregressive Distributed Lag approach and Granger causality test used monthly data from 2013-2019. The results showed that the Islamic banking core depositors are more sensitive to the performance of Capital Adequacy Ratio (CAR), the Exchange rate (FEX), and the Repo rate (RRA). Meanwhile, conventional core depositors are sensitive to Loan to Deposit Ratio (LDR) and FEX. The impact of core depositors' sensitivity to liquidity risk has been seen in conventional banks, while the core depositors of Islamic banks have no impact on liquidity risk. This paper specifically complements the previous research on the analysis of core depositors and that it can be used as an early warning sign of liquidity risk on Islamic and conventional banks in Indonesia.
\end{abstract}

\section{KEY WORDS}

Core depositors, banking performance, Islamic banking, macroeconomics, Autoregressive Distributed Lag (ARDL).

Indonesia is a country that implements a dual banking system, which aims to bring more complete alternative banking services to the public (Bank Indonesia, 2012). Within the framework of the Indonesian Banking Architecture (Arsitektur Perbankan Indonesia abbreviated as API), the Islamic banking system and conventional banking synergize to supporting broader public mobility of funds to enhance financing capabilities for sectors of the national economy (Bank Indonesia, 2012). Islamic banks as alternative financial services have been initiated since the 1980s. As of July 2019, Islamic banks have posted assets of USD 35.53 billion, financing of USD 24.05 billion, third party funds of USD 27.53 billion, and profit of USD 0.81 billion with the support of 14 (fourteen) Islamic Commercial Banks (ICB), 20 (twenty) Sharia Business Units (SBU) and 99 (ninety-nine) Sharia Financing Banks (SFB) that have operated in Indonesia (OJK, 2019).

Even though, there are an increase in assets, financing, and third-party funds, but, its slowdown in business volume growth has been seen in the last five years. Until the end of 2019, the market share of Islamic banks only reached 6.01 percent (OJK, 2019). Bank as an intermediary institution function, both Islamic banks and conventional banks must be able to 
help the growth of the macroeconomy, so that the government, in this case, the central bank of Indonesia as the mandate holder in maintaining financial system stability and Financial Services Authority (Otoritas Jasa Keuangan) as a supervisor of financial institutions, must be able to encourage the intermediation function of Islamic banks and identify a slowdown in Islamic bank business (Gunadi \& Taruna, 2015).

The reasons for slowing of the Islamic bank business in Indonesia were caused by several things, namely (OJK, 2015): First, expensive fund costs which have an impact on the financing segment limitations, so that the funding structure of Islamic banks has not been able to be as efficient as Conventional banks, this is reflected in Cash and Saving Accounts (CASA) and operating costs to operating income (BOPO). Although in trend, Islamic banks continue to reduce the BOPO ratio as of 2018 July, the BOPO ratio is 85.58 percent, but it is still higher than the conventional banks which are only 81.08 percent. The inefficiency of Islamic banks has caused the business model to only be optimized in the retail and consumer sectors with relatively limited margins so that the achievement of Return on Assets (ROA) is relatively low (OJK, 2015). Besides, the business model that is more focused on the retail and consumer sectors has a long-term tenor causing a short-term mismatch in Islamic banks. In July 2019, the total short-term assets of Islamic banks were only able to pay 25.39 percent of short-term liabilities (OJK, 2019), which cause Islamic banks should provide liquidity risk reserve to the short term mismatch of 74.61 percent.

Second, understanding and awareness of the community are still low so that Islamic bank customers are only dominated by certain groups called core depositors. Core depositors are the largest depositors of funds both in current accounts, savings, and deposits with the number of core depositors determined based on total bank assets (Bank Indonesia, 2011). The behavior of these core depositors tends to place their funds on deposit products with a high return rate because the yield provided is higher compared to savings or current account products (OJK, 2015). In 2018, the composition of fund placements in deposit products reached 57.00 percent of the total DPK with the dominance of core depositors at 36.06 percent of all Islamic Commercial Bank depositors (OJK, 2019). While at the end of July 2019, the composition of fund placements in deposit products decreased to 54.84 percent of the total DPK with the dominance of core depositors being 33.51 percent (OJK, 2019).

Third, the influence of the behavior of core depositors who (a) carry out displaced commercial risk if conventional bank interest rates are higher than the return of Islamic banks (Kasin \& Kassim, 2009). Displaced commercial risk is a unique risk that must be faced by Islamic banks, this risk is shown when interest rates for depositors are competitive, whereas Islamic banks operating on the principle of profit sharing will face fluctuating rates of return, resulting in the potential for transfer of Islamic bank depositors to conventional (Khan \& Ahmed, 2011). (b) withdraw funds by customers at any time, (c) have two or more accounts with conventional banks and Islamic banks, making it easier to transfer funds between banks. In the condition of the dominance of core depositors affected by these behaviors, and Islamic banks must control liquidity risk and maintain loyalty from depositors because Islamic bank depositors are more sensitive to return (Akhtar, 2016).

Slowing business volume can also illustrate the ability of banks to manage assets and liabilities to obtain profits and increase the value of the company within certain limits. Wuryandani et al. (2014) explains that what is meant by certain limits includes an adequate level of liquidity, low risk, and sufficient capital. So it is clear that asset and liability management is closely related to bank liquidity. According to Ismal (2010), the three main causes of potential liquidity problems are (i) rational depositors who are very sensitive to interest rates, (ii) most deposit placements within a period of one month, causing limitations of Islamic banks to arrange optimal financing allocations, and (iii) macroeconomic factors, especially interest rate trends that cause rational depositors to transfer their deposits from sharia banks to conventional banks.

When compared to Islamic banks, conventional banks are better in managing liquidity. This is because the availability of money markets such as the discount of bills or investments in securities is easier to do by conventional banks that are not bound to sharia compliance (Islam et al. 2017). 
On the other hand, the financial crisis, inflation, and economic growth have an influence on the behavior of customers in placing their funds in banks that affect bank liquidity, in line with Wuryandani et al. (2014) that bank liquidity is more determined by operational conditions, capital, financial system, and macroeconomic conditions. Soprano (2015) confirmed, based on the results of his research that macroeconomic factors such as interest rates have a significant influence on customer behavior, furthermore, Abduh et al. (2011) explained that the relationship between macroeconomic factors in the form of inflation had a negative influence on the total deposits of Islamic banks which reflected changes in the consumption patterns of depositors during the recession.

The finding of this research is important to conduct a sensitivity analysis of core depositors and should be the focus of the bank in determining the direction of the business to mitigate the possibility of liquidity risk which will later hamper the bank in increasing profitability and business performance. Besides, this sensitivity analysis of core depositors will also be an early warning sign of liquidity indicators that can predict liquidity pressures originating from the dominant funds from core depositors.

Meanwhile, the purpose of this study is to analyze the factors that influence the sensitivity of core depositors in Islamic banks and conventional banks, which are presented in five sections, are an introduction which has been discussed in the previous section, literature review, research method, result of study, and conclusions.

\section{LITERATURE REVIEW}

Liquidity risk management is a core competency for every financial institution including banks. In general, liquidity risk is divided into two, namely funding liquidity risk and market liquidity risk. Funding liquidity risk is the risk that arises because banks are unable to liquidate assets owned or obtain funding loans from other funding sources. Whereas market liquidity risk is the risk caused by the inability of banks to liquidate assets without being subjected to material discounts due to the absence of an active market or the presence of severe market disruption (Banker Associaton of Risk Management, 2010).

The importance of identifying liquidity needs on time and safety can be an early warning indicator of liquidity risk, especially on factors that affect liquidity risk including a decrease in confidence in the banking system, dependence on core depositors, and high short-term funds (Rivai, 2013). Therefore, funding liquidity risk focuses on the availability of fund guarantee obligations which can be withdrawn at any time to generate cash either in the short term or long term (Banks, 2014).

Freixas \& Rochet (2008) explained that basically, bank liquidity risk management is not much different from companies because in general it will always be related to inventory management, but for some things, liquidity risk at banks must be dealt quickly because it will affect other banks and pose risks of liquidity. According to them, maximizing profits can encourage liquidity balance in terms of assets and liabilities. The formulation of the bank profit model results from:

$$
\pi=r_{L} L+r M-r_{D} D-C(D, L)
$$

Where: $\pi$ bank profit, $r_{L}$ Interest credit, $L$ Credit (loan), $D$ Deposits of Third Party Funds, and $C$ Costs.

Ismal (2010) refers to the formulation of the Freixas and Rochet model and formulates a sharia bank liquidity balance model adjusted to sharia principles, namely: (i) changing the term of credit $\left(r_{L}\right)$ to financing $\left(r_{f}\right)$, (ii) prohibition on transactions containing riba, maysir, and gharar, (iii) use the principle of profit and loss sharing so that the principle of savings interest $\left(r_{D}\right)$ becomes profit sharing $(r \beta)$, and produces the following model:

$$
\pi=\left[\left(r_{f} F+r M\right)(1-r \beta)-C(D, F)\right]+\left[r_{i} L-C(L)\right]
$$

Banks as intermediary institutions have the function of collecting and distributing public 
funds, so based on these functions the bank carries out operational activities by providing savings and financing facilities (Haron \& Azmi, 2009). PBI no. 13/19/PBI/2011 concerning Amendments to Bank Indonesia Regulations no. 8/12/PBI/2006 concerning Commercial Bank Periodic Reports, that what is meant by core depositors is 10 (ten), 25 (twenty-five), or 50 (fifty) depositors the largest of current accounts, savings, and deposits by the total assets of the bank, with the following asset categories: a) for banks that have total assets up to one trillion rupiahs covering the 10 (ten) biggest depositors; $b$ ) for banks that have total assets more than one trillion rupiahs to ten trillion rupiahs covering 25 (twenty-five) biggest depositors; and $c$ ) for banks that have a total asset more than ten trillion, covering 50 (fifty) biggest depositors.

Dependence on core depositors will affect banks in managing liquidity from funding activities, while changes in the behavior of core depositors will also affect the placement of funds in banks. The calculation of the Core Depositors Ratio (CDR) and Growth of the Core Depositors Ratio (GCDR) is used to measure the amount of Islamic banks' dependence on funds from the core depositors. The higher the CDR ratio, the greater the liquidity risk faced by Islamic banks, while the GCDR is the ratio used to measure growth the level of dependence of Islamic Banks on core depositors, with the following formula (Bank Indonesia, 2011a):

$$
\begin{aligned}
& \mathrm{CRD}=D P K_{\text {int }} \text { it } \frac{D P K_{\text {int }} \text { it }}{D P K_{\text {it }}} \\
& \mathrm{GCDR}=\frac{D P K_{\text {int } t}-D P K_{\text {int } t-1}}{D P K_{\text {int }} t-1}
\end{aligned}
$$

Where: the CDR is the Core Depositors Ratio, the GCDR is Growth of the Core Depositors Ratio, the $\mathrm{DPK}_{\text {int }}$ is the third-party funds from the Core Depositors per certain period, while the $D P K_{i t}$ is the third-party funds per certain period.

Assessment of bank performance through financial ratios has several methods, including the CAMEL (Capital, Asset, Management, Earnings, and Liquidity) approach. Meanwhile, different terms were conveyed by Gitman \& Zutter (2015) which explained tha the five general categories of measurement of financial ratios, namely liquidity, activity, debt, profitability, and market ratio. Kasmir (2008) outlines several important bank financial ratios including liquidity ratios, solvency ratios, and profitability ratios.

Liquidity ratio is the ratio used to measure the ability of banks to meet short-term obligations when billed. In other words, this ratio also illustrates the ability of banks to repay the disbursement of depositors at the time of collection and can meet the demand for credit that has been submitted, so that the greater this ratio, the more liquid the bank (Kasmir, 2008).

Kasmir (2008) also explains that the solvency ratio is a measuring tool to see bank wealth and the level of efficiency of a bank. While the profitability ratio is a measuring tool in seeing the business efficiency achieved by a bank. Gitman (2011) explains that the main concern of fund owners (creditors) is short term liquidity and the ability of banks to return the principal along with the return of funds deposited, then the second concern is the profitability of companies that can provide guarantees to depositors that funds are deposited in banks will be safe. Then, in that case, several financial ratios that are often used in measuring performance in the banking industry, in particular, those of concern to fund owners include the following:

Finance to Deposit Ratio (FDR). This ratio is used to measure the composition of the amount of funding disbursed compared to the number of funds raised (Kasmir 2008), this ratio can also be used as an assessment in measuring bank liquidity (Latumaerissa, 1999). So the high FDR ratio indicates the low ability of banks to repay customer deposits when withdrawn at any time. This is because of too much used to finance the bank's business in financing distribution. The FDR formulation is as follows (OJK, 2014):

$$
\frac{\text { Total Loans }_{i t}}{\text { Total third-party funds it }}
$$

Capital Adequacy Ratio (CAR). This ratio is used to measure capital and write off reserves in the financing, especially those caused by defaults on customers (Kasmir, 2008). 
Harahap (2010) clearly states that CAR is a ratio that shows the capital adequacy set by regulators that specifically applies to industries that are under government supervision. The higher the CAR, the more protected the bank from default because CAR is the initial protection against capital-based failures (Bessis, 2015a). The CAR formulation is as follows (OJK, 2014):

$$
\frac{\text { Bank capital }}{\text { Risk weighted assets }}
$$

Return on Asset (ROA). This ratio shows the effectiveness of overall bank management in generating profits from assets owned (Gitman 2011a). The higher ROA, the greater the level of bank profit (Gitman 2011), so that the possibility of banks in problematic conditions are getting smaller (Machmud and Rukmana, 2010), with the following formula (OJK, 2014):

$$
\frac{\text { Net Income }_{\text {it }}}{\text { Total Assets }} \text { it }
$$

Operational costs to operating income (BOPO). Operating Expenses are bank expenses including profit sharing and bonuses (annualized), while Operational Income is fund distribution revenue (OJK, 2014). BOPO ratio shows the level of bank efficiency, the higher the BOPO ratio, the lower the level of bank efficiency. Based on this, BOPO has a negative relationship with bank performance (Muljono, 1999). The BOPO formulation is as follows (OJK, 2014):

$$
\frac{\text { Total Operational } \text { Costs }_{i t}}{\text { Total Operating } \text { Income }_{\text {it }}}
$$

Macroeconomic factors can represent the economic condition of a country so that it can influence investment activities including the activities of depositors in placing their funds in banks (Kuncoro 2006). Manurung (2004) states that monetary policy directs the macroeconomy to the desired conditions by changing the money supply. Besides, Manurung (2004) also explained that fiscal policy directed the macroeconomy to a better condition by making changes to the amount of government revenue and expenditure, so it was not surprising that macroeconomics discussed many problems in the form of unemployment, inflation and financial stability (Dorman, 2014).

Banks as institutions for collecting and channeling public funds aim to support the implementation of national development that affects macroeconomic aspects. The influence of the bank on the macro aspect is explained by Keynes \& Schumpeter (1954) which was conveyed again by Giancarlo (2009) that the concept of a bank is not only related to credit and savings (savings) but also creates the replacement of money with a payment system with the authority to issue checks as a payment tool, so with that authority, the bank can influence the money supply. Keynes further explained in general theory about the money supply that illustrates two phenomena regarding the demand and supply of money, namely: first, the demand for liquidity from companies with financial deficits, so that they choose credit or debt to finance their business. Second, offering liquidity from companies or agents with financial surpluses. Those two conditions, according to Keynes, financial markets, and credit markets are needed as a liquidity solution. Based on these reasons, Tsang (1980) restated the function of money supply-demand by assuming the two following conditions in the money market and credit market:

$$
\Delta \mathrm{M}_{\mathrm{t}}^{\mathrm{s}}=\Delta \mathrm{M}_{\mathrm{t}}^{\mathrm{d}}=\mathrm{kl}_{\mathrm{t}}^{\mathrm{p}}-\mathrm{k}\left(\mathrm{Y}_{\mathrm{t}-1}-\mathrm{C}_{\mathrm{t}}^{\mathrm{p}}\right)+\mathrm{L}\left(\mathrm{r}_{\mathrm{t}}, \mathrm{W}_{\mathrm{t}}\right)-\mathrm{L}\left(\mathrm{r}_{\mathrm{t}-1}, \mathrm{~W}_{\mathrm{t}-1}\right)
$$

Where: $\mathrm{M}_{\mathrm{t}}^{\mathrm{s}}$ money supply, $\mathrm{M}_{\mathrm{t}}^{\mathrm{d}}$ money demand, $\mathrm{I}_{\mathrm{t}}^{\mathrm{p}}$ investment plan a certain time, $\mathrm{Y}$ income, $\mathrm{C}_{\mathrm{t}}^{\mathrm{p}}$ $t$ a certain time consumption plan, $r_{t}$ current rate of interest, and $W_{t}$ value of total wealth.

Equation (9) shows that the macroeconomic condition of the money supply is affected by the balance of the loanable funds market because the allocation of funds which is the main source of income for banks is credit. The inability of banks to solve the problem of balance in the fund market will result in difficulties fulfill obligations to depositors as owners of third party 
funds (Giancarlo, 2009).

Since the global crisis, banking institutions have begun to concentrate on studying this phenomenon, even BASSEL as a banking association has updated risk controls to protect banks. One of them with the macroprudential concept which has now been applied also in Indonesia with the issuance of PBI number 20/4/PBI/2018 dated 29 March 2018 concerning the ratio of macroprudential intermediation and the operation of macroprudential liquidity for conventional commercial banks, Islamic commercial banks, and Islamic business units. The macroprudential regulation and supervision aim to prevent and reduce systemic risk and encourage a balanced and quality intermediary function so that the need for intermediation and liquidity-based macroprudential instruments is formulated that takes into account the economic cycle.

Hoflich (2011), states that macroprudential must be able to supervise three things, namely: first, supervision of capital structure with the consideration that capital must be higher for companies or institutions that have high risks to the financial system. Second, oversight of liquidity risk and asset and liability management, including oversight of external indicators, including increased withdrawal of deposits before maturity influenced by negative information on the bank, continuous increase in share prices and macroeconomic factors so limiting banks' ability to obtain long-term funding (Banker Association for Risk Management, 2011). Third, oversight of risk management of systemically important institutions, so that it has a strong and effective way of evaluating risk, minimizing the likelihood of a risk occurring, and the importance of government support to avoid the spread of widespread financial instability.

Inflation. Inflation is a general and continuous price increase that can reduce the level of corporate investment and public purchasing power, one indicator to determine the inflation rate is the Consumer Price Index (CPI) (Rahardja and Manurung 2008). Rahardja and Manurung (2008) explain that the CPI is a measure of the price level of goods and services that consumers buy at a certain time. Soebagiyo and Prasetyawati (2002) explained that the CPI is calculated per month based on the price development of goods and services consumed by households in all provincial capitals in Indonesia. Inflation is measured by the average price, and the effect of inflation must always be considered, this is to compare the economic value from time to time (Dorman, 2014).

The effect of inflation on core depositors is in line with the results of Purnamahadi's research (2011) which explains that the dominant amount of deposits owned by core depositors is significantly influenced by inflation and interest rates.

Gross Domestic Product (GDP). Rahardja and Manurung (2008) explain that the GDP of a country can reflect the country's economy, as well as can be used to analyze the level of public welfare. Dorman (2014) explains, although still not perfect, GDP is the only indicator to predict the level of production of both goods and services during a certain period. Similar to inflation, GDP substantially fluctuates in the short term, starting from the quarter to the year, so that countries experiencing an increase in GDP indicate the welfare of the people in the country also increased. These statements are in line with the opinion of Mankew (2003) which explains that one of the macroeconomic variables as the best measure in measuring a country's economic performance is GDP.

Repo Rate 7 Day Bank Indonesia (the central bank of Indonesia). Since August 19, 2016, the central bank of Indonesia has strengthened the monetary operating framework by implementing a benchmark interest rate or a new policy rate called the BI 7-day (Reverse) Repo Rate. The strengthening of the framework of the monetary operations is carried out to strengthen the effectiveness of policies in achieving the inflation targets set. The BI 7-day (Reverse) Repo Rate instrument was used as a new policy rate because it can quickly affect the money market, banking, and the real sector. The BI 7-day (Reverse) Repo Rate instrument as a new reference has a stronger relationship to money market interest rates, is transactional or traded on the market, and encourages financial market deepening, specifically the use of repo instruments (Bank Indonesia, 2016b). The relationship of the central bank's benchmark interest rate with depositors' deposits, explained by Fry (1989) in Kuncoro (2006) that interest rates can cause bias in encouraging current consumption and ignoring future consumption, resulting in savings and investment below the optimum level. 
Exchange rate. The exchange rate is the relative price of one currency against another (Moosa, 2003). In calculation, there are two types of exchange rates, namely the nominal exchange rate and the real exchange rate. The nominal exchange rate is the relative price of two currencies of two countries or can be called a bilateral exchange rate because it only compares the currencies of two countries, while the real exchange rate is the prices in the country compared to foreign prices measured by currency with the same money (Dornbusch, 2008). The exchange rate can be formulated as follows:

$$
R=e \frac{P f}{P}
$$

Where: $\mathrm{R}$ is the exchange rate, while $P$ is the domestic price, $P_{f}$ is the foreign price, and $e$ is the nominal exchange rate.

Kuncoro (2006) stated that uncertainty about foreign exchange rates resulted in inhibited savings activities even though investment opportunities were quite good. Also, Kuncoro (2006) stressed the loss of public confidence in the domestic currency resulting in the flight of domestic capital and replacing the currency held from the domestic currency into a foreign currency.

\section{METHODS OF RESEARCH}

The data used in this study has been secondary data in the form of monthly data obtained from Financial Statements, Islamic and conventional banking Statistics from the Islamic and conventional bank website and the Financial Services Authority (Otoritas Jasa Keuangan). The macroeconomic factors in the form of inflation data, GDP, repo rates and exchange rates are obtained from the Bank Indonesia website. The research data are time series with data periods from 2013 to 2019 July.

Analysis of the sensitivity of core depositors to the performance of Islamic banks and macroeconomic factors is measured based on the ratio using dynamic models and tools of Eviews version 9 (nine) using variables:

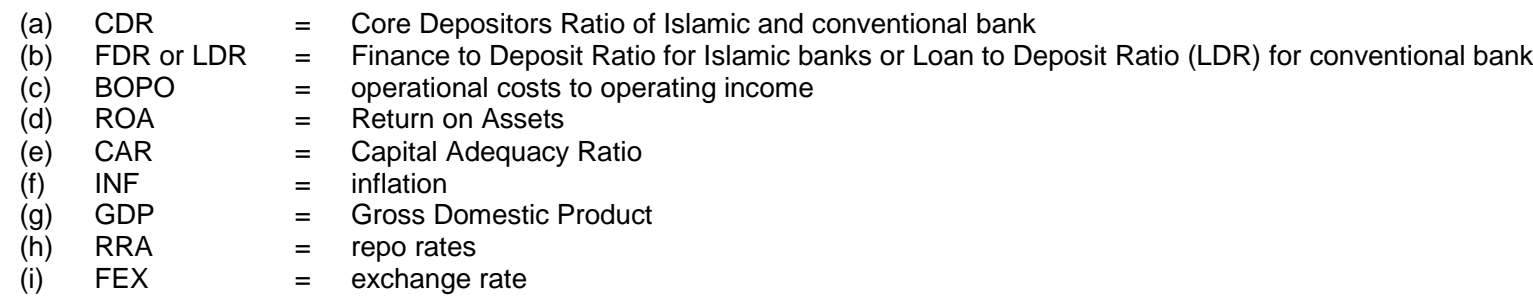

Data processing and analysis techniques in this study used the econometric approach with the Autoregressive Distributed Lag (ARDL) model. ARDL requires the establishment of a long-term relationship between variables using the Ordinary Least Squares (OLS) technique on an unrestricted error correction model. Before processing data with ARDL, several tests were carried out, namely the pre-estimation of data stationarity testing with unit roots, correlation test, Granger Causality test. Granger Causality Testing aims to see the relationship between variables in the model as seen from the influence of the past, on the present or the future. The ARDL model for Islamic and conventional bank uses the equation, which is as follows:

$$
\begin{aligned}
\Delta C D R_{t}= & \alpha_{0}+\sum_{k=1}^{n} a_{k} \Delta C D R_{t-k}+\sum_{k=0}^{n} b_{k} \Delta F D R_{t-k}+\sum_{k=0}^{n} c_{k} \Delta B O P O_{t-k}+\sum_{k=0}^{n} d_{k} \Delta R O A_{t-k}+\sum_{k=0}^{n} e_{k} \Delta C A R_{t-k}+ \\
& \sum_{k=0}^{n} f_{k} \Delta I N F_{t-k}+\sum_{k=0}^{n} g_{k} \Delta G D P_{t-k}+\sum_{k=0}^{n} h_{k} \Delta R R A_{t-k}+\sum_{k=0}^{n} i_{k} \Delta F E X_{t-k}+u_{t}
\end{aligned}
$$

Where: CDR is core depositors, FDR is Finance to Deposit Ratio, BOPO is Operational Cost to Operating income, CAR is Capital Adequacy Ratio, INF is Inflation, GDP is Gross Domestic Product, RRA is Repo Rate and FEX is foreign exchange, while $\Delta$ is differentiated in the first order. 
Meanwhile, the Granger Causality test aims to see the relationship between the variables in the model. Granger (1969) in Firdaus (2011) explains that by using the F-test to show whether the information lag in the dependent variable provides statistically significant information about the independent variable in explaining the independent variables change. If not, there is no Granger causal relationship between them.

\section{RESULTS OF STUDY}

Data stationary test results showed that data has been fully stationarity at the 1st difference level, as seen in Table 1:

Table 1 - Stationarity Test with Unit Roots

\begin{tabular}{|c|c|c|c|c|}
\hline \multicolumn{5}{|c|}{ Islamic Bank } \\
\hline \multirow[t]{2}{*}{ Variable } & \multicolumn{2}{|l|}{ Augmented Dickey Fuller (ADF) } & \multicolumn{2}{|c|}{ Phillip and Perron (PP) } \\
\hline & Level & $1^{\text {st }}$ difference & Level & $1^{\text {st }}$ difference \\
\hline CDR & -2.366816 & $-6.245460^{*}$ & -2.420896 & $-6.293179^{*}$ \\
\hline CAR & -1.112198 & $-9.310096^{*}$ & -0.742820 & $-10.01200^{*}$ \\
\hline BOPO & -2.825380 & $-7.343948^{*}$ & -2.853986 & $-8.525717^{*}$ \\
\hline FDR & -0.849176 & $-9.586800^{*}$ & -0.849176 & $-9.640946^{*}$ \\
\hline $\mathrm{ROA}$ & -2.831258 & $-8.352615^{\star}$ & -3.034288 & $-10.24458^{*}$ \\
\hline INF & -1.408258 & $-6.299225^{\star}$ & -1.610833 & $-6.138902^{*}$ \\
\hline GDP & -2.573254 & $-8.026230^{*}$ & -2.703670 & $-8.071452^{*}$ \\
\hline RRA & -1.190898 & $-4.907081^{*}$ & -1.223535 & $-4.959038^{*}$ \\
\hline FEX & -2.016276 & $-7.708513^{*}$ & -2.016276 & $-7.708513^{*}$ \\
\hline \multicolumn{5}{|c|}{ Conventional Bank } \\
\hline CDR & $-6.600609^{*}$ & $-13.95688^{*}$ & $-6.694831^{*}$ & $-27.67721^{\star}$ \\
\hline CAR & -1.016914 & $-9.156382^{*}$ & -0.974970 & $-9.159311^{*}$ \\
\hline Variable & Augmented Dickey Fuller (ADF) & & \multicolumn{2}{|c|}{ Phillip and Perron (PP) } \\
\hline & Level & $1^{\text {st }}$ difference & Level & $1^{\text {st }}$ difference \\
\hline $\mathrm{BOPO}$ & -2.595045 & -1.791935 & -2.534656 & $-11.60963^{*}$ \\
\hline LDR & -2.205681 & $-7.744585^{*}$ & -2.205681 & $-7.710737^{\star}$ \\
\hline $\mathrm{ROA}$ & -1.128855 & $-5.489762^{*}$ & -1.171076 & $-5.585437^{*}$ \\
\hline INF & -1.833690 & $-6.604812^{*}$ & -1.530535 & $-6.348233^{*}$ \\
\hline GDP & -2.593787 & $-8.388142^{*}$ & -2.716559 & $-8.432376^{*}$ \\
\hline RRA & -1.128855 & $-5.489762^{*}$ & -1.171076 & $-5.585437^{\star}$ \\
\hline FEX & -2.052344 & $-9.313665^{\star}$ & -2.063689 & $-9.316369^{*}$ \\
\hline
\end{tabular}

Note: *) stationarity level $1 \%$.

ARDL dynamic model estimation is based on the Granger Causality test results. Based on the test of eight variables consisting of four performance variables in the form of FDR, ROA, BOPO, and CAR as well as inflation of macroeconomic variables (INF), GDP, Repo Rate (RRA) and exchange rates (FEX), only CAR, RRA, and FEX variables have a Granger Causality in Islamic banking models. Whereas in the Islamic Banking model, only LDR and RRA variables have a Granger Causality.

Table 2 - Granger Causality Test Results

\begin{tabular}{lccc}
\hline Null Hypothesis & F-Stat & P-Value & Conclusion \\
\hline Islamic Bank & & & \\
\hline D(CAR) does not Granger Cause D(CDR) & 2.96570 & 0.0594 & not accepted \\
\hline D(RRA) does not Granger Cause D(CDR) & 10.7634 & 0.0001 & not accepted \\
\hline D(FEX) does not Granger Cause D(CDR) & 2.51499 & 0.0896 & not accepted \\
\hline Conventional Bank & & & \\
\hline D(LDR) does not Granger Cause D(CDR) & 4.79850 & 0.0114 & not accepted \\
\hline D(RRA) does not Granger Cause D(CDR) & 4.82817 & 0.0111 & not accepted \\
\hline
\end{tabular}

Based on the Granger Causality Test, the estimation test using the ARDL dynamic model is only performed on CAR, LDR, RRA, and FEX variables. 
Table 3 - Estimation Results of ARDL Islamic Bank

\begin{tabular}{|c|c|c|c|c|}
\hline Variable & Coefficient & Std. Error & t-Statistic & Prob. \\
\hline $\mathrm{C}$ & -0.002982 & 0.002679 & -1.113064 & 0.2699 \\
\hline $\mathrm{D}(\mathrm{CDR}(-1))$ & -0.060471 & 0.009764 & -6.193370 & 0.0000 \\
\hline $\mathrm{D}(\mathrm{CAR}(-2))$ & 0.076593 & 0.037012 & 2.069403 & 0.0426 \\
\hline $\mathrm{D}(\operatorname{RRA}(-1))$ & -0.504650 & 0.124353 & -4.058207 & 0.0001 \\
\hline $\mathrm{D}(\operatorname{RRA}(-2))$ & -0.258328 & 0.138532 & -1.864761 & 0.0669 \\
\hline $\mathrm{D}(\mathrm{FEX}(-1))$ & -0.001613 & 0.000850 & -1.898542 & 0.0622 \\
\hline R-squared & 0.496080 & \multicolumn{2}{|c|}{ Mean dependent var } & -0.002233 \\
\hline Adjusted R-squared & 0.456087 & \multicolumn{2}{|c|}{ S.D. dependent var } & 0.029114 \\
\hline S.E. of regression & 0.021471 & \multicolumn{2}{|c|}{ Akaike info criterion } & -4.761245 \\
\hline Sum squared resid & 0.029044 & \multicolumn{2}{|c|}{ Schwarz criterion } & -4.566975 \\
\hline Log likelihood & 170.2630 & \multicolumn{2}{|c|}{ Hannan-Quinn criter. } & -4.684172 \\
\hline F-statistic & 12.40398 & \multirow{2}{*}{\multicolumn{2}{|c|}{ Durbin-Watson stat }} & 1.809413 \\
\hline Prob(F-statistic) & 0.000000 & & & \\
\hline
\end{tabular}

Based on ARDL dynamic estimation results using time series data from 2013 to 2018, it is known that the growth of core depositors at Islamic Commercial Banks (ICB) is influenced by the core depositors variable itself. The effect is seen in lag $(-1)$ or the previous one months of 0.06 (6.04 percent), this condition is influenced by the dominant type of depositors in deposit products with a period of one month. The dominance of deposit products owned by depositors over the past five years with an average of 71.99 percent a year, meaning that in the short term the growth of core depositors' funds is influenced by the core depositors variable themselves in the previous period. This will certainly risk liquidity shocks due to differences in nature assets (investments) and liabilities (deposits) where the financing period is fixed, while deposit liabilities depend on the behavior of depositors. This research supports Ismal (2010) that one of the three main causes of liquidity problems is the majority of deposit placements within one month.

The difference is like the owner of the fund, especially the core depositors that dominate funds in Islamic banks to more than 30 percent, makes Islamic banks must continue to maintain the trust of core depositors to keep their funds in Islamic banks. As a financial intermediary institution, Islamic banks must continue to maintain professionalism and credibility as the main capital of financial institutions.

From internal factors, the sensitivity of core depositors is dominantly influenced by the performance of bank capital, visible growth of core depositors is influenced by the variable Capital Adequacy Ratio (CAR) in the previous month of 0.07 (7.65 percent). It is understood that bank capital is the main indicator in assessing the ability of banks in dealing with economic shocks, as Besses (2015) argues, the higher the CAR, the more protected the bank from default because CAR is the initial protection against capital-based failures.

The high level of sensitivity of core depositors to CAR variables must be a concern because bank capital collection is not only from own capital but comes from third-party funds or customers in the form of deposits. The causality of core depositors to CAR and CAR to core depositors is evidenced by the results of research showing a two-way relationship that influences each other.

Meanwhile, the biggest macroeconomic factor which negatively affecting core depositors is the Repo Rate (RRA) to reach -0.50 or 50.46 percent (lag 1 ) and -0.25 or 25.83 percent (lag 2). The results of this study prove that the depreciation of core depositors in the 2013-2018 research period proves the existence of the commercial risk of funds that displaced from Islamic banks to conventional banks. It was proven that RRA was responded positively by conventional bank core depositors in lag 2.

The high sensitivity of core depositors to the RRA to reach 0.50 , should be used as a reference for Islamic banks as a variable that is taken into account in stress testing of liquidity risk. This is important because the results of the research indicate the negative influence of the RRA on the growth of core depositors. The high influence of the RRA is in line with Susandi's (2015) study which states that although the RRA has a small portion in influencing the liquidity of Islamic banks in Indonesia, it must be a concern for them.

Furthermore, another variable that affects the sensitivity of Islamic bank core depositors is the exchange rate (FEX). The research proves that FEX negatively affects by $0.001(0.1$ 
percent). The results of the data test support the opinion of Kuncoro (2006) which explains that the uncertainty of the foreign exchange rate results in savings activities are hampered even though investment opportunities are good. But the effect of FEX is not seen in the conventional bank model estimation test. This is in line with the results of Iskandar and Firdaus's (2014) research which explains that the exchange rate does not affect conventional bank deposits on deposit products.

Table 4 - Estimation Results of ARDL Conventional Bank

\begin{tabular}{|c|c|c|c|c|}
\hline Variable & Coefficient & Std. Error & t-Statistic & Prob. \\
\hline $\mathrm{C}$ & 0.014379 & 0.030995 & 0.463913 & 0.6444 \\
\hline $\mathrm{D}(\mathrm{CDR}(-1))$ & -0.497195 & 0.098202 & -5.062991 & 0.0000 \\
\hline $\mathrm{D}(\mathrm{CDR}(-2))$ & -0.231499 & 0.091179 & -2.538955 & 0.0137 \\
\hline $\mathrm{D}($ LDR $)$ & -0.817295 & 0.373928 & -2.185704 & 0.0327 \\
\hline $\mathrm{D}(\operatorname{LDR}(-1))$ & -0.118270 & 0.039072 & -3.026954 & 0.0036 \\
\hline $\mathrm{D}(\mathrm{RRA}(-2))$ & 0.784565 & 0.147795 & 5.308463 & 0.0000 \\
\hline R-squared & 0.617826 & \multicolumn{2}{|c|}{ Mean dependent var } & -0.007241 \\
\hline Adjusted R-squared & 0.580235 & \multicolumn{2}{|c|}{ S.D. dependent var } & 0.384540 \\
\hline S.E. of regression & 0.249140 & \multicolumn{2}{|c|}{ Akaike info criterion } & 0.155649 \\
\hline Sum squared resid & 3.786330 & \multicolumn{2}{|c|}{ Schwarz criterion } & 0.384128 \\
\hline Log likelihood & 1.707940 & \multicolumn{2}{|c|}{ Hannan-Quinn criter. } & 0.246179 \\
\hline F-statistic & 16.43550 & \multirow{2}{*}{\multicolumn{2}{|c|}{ Durbin-Watson stat }} & 2.120004 \\
\hline Prob(F-statistic) & 0.000000 & & & \\
\hline
\end{tabular}

Meanwhile, looking at the Granger Causality test results (Table 2) on Islamic banks shows that there is no proven relationship between the core depositors' causality to liquidity (FDR). However, conventional banks which show a causality relationship between core depositors and liquidity (FDR), this is due to the stable total amount of core depositors at conventional banks, while the number of loans continues to increase as reflected in the LDR ratio to more than 90 percent since 2015 .

\section{CONCLUSION}

Slowing growth in the Islamic banking business has been caused by low public understanding and awareness. So, that Islamic bank customers have been dominated by certain groups (core depositors) as well as the behavior of the core depositors who displace commercial risk and can withdrawals at any time on their accounts at Islamic banks, the profitability of Islamic banks is not yet optimal. This study showed the core depositors of Islamic banks were more sensitive to the performance of the Capital Adequacy Ratio (CAR). Meanwhile, on macroeconomic factors, core depositors have been more sensitive to Repo Rate (RRA) and exchange rate (FEX).

Islamic bank core depositors are not directly affected by Islamic bank liquidity risk. While in a conventional bank, core depositors have been proven to influence liquidity as indicated by the causality relationship between conventional bank core depositors to LDR based on the Granger Causality test.

Finally, the Islamic bank should maintain liquidity to keep the balance sheet from the asset and liabilities by optimizing profit and pushing the CAR to the position above the threshold over 8 percent. In addition, the Islamic bank should be able to reduce the introduction of products besides deposits to the depositor to suppress the BOPO ratio and increase the CASA ratio. Meanwhile, as a liquidity security strategy, the Islamic bank has to continue to identify and calculate cash inflows and outflows in the short term, as well as analyzing the behavior of core depositors and striving for funds deposited by core depositors to become the main source of funds (core deposits) through prime customer categorization.

\section{REFERENCES}

1. Abduh, M., Mohd, A. O., \& Jarita, D. (2011). The Impact of Crisis and Macroeconomic Variables Towards Islamic Banking Deposits. American Journal of Applied Sciences. 8(12): 1413-1418. 
2. Akhtar, B., Waheed, A., \& Muhammad, S. (2016). Determinants of Deposits in Conventional and Islamic Banking: a Case of an Emerging Economy. International Journal of Emerging Markets. 12(2): 296-309. Emerald Publishing Limited 1746-8809 DOI 10.1108/IJoEM-04-2015-0059.

3. [BI] Bank Indonesia. (2018), "PBI nomor 20/4/PBI/2018 tanggal 29 Maret 2018 tentang Rasio intermediasi makrofrudensial and penyelenggaraan likuiditas makroprudensial bagi bank umum konvensional", Bank Indonesia.

4. Banks, E. (2014). Liquidity risk managing funding and asset risk second edition. United Kingdom: Palgrave Macmillan.

5. [BARa] Banker Association for Risk Management. (2013). Modul uji kompetensi profesi bankir bidang manajemen risiko level 2 edisi 3. Jakarta: Lembaga Sertifikasi Profesi Perbankan.

6. Bessis, J. (2015). Risk management in banking fourth edition. United Kingdom: John Wilwy \& Sons Ltd.

7. Freixas, \& Rochet. (2008). Microeconomics of banking second edition. London: The MIT Press.

8. Giancarlo, B. (2009). On Keynes's Criticism of the Loanable Funds Theory. Università Dell'insubria [internet]. (diakses pada: 2019 Oktober 10). Tersedia pada: https://www.researchgate.net/publication/46464647_On_Keynes's_Criticism_of_the_Loa nable_Funds_Theory.

9. Gitman, L. J., \& Zutter, C. J. (2011). Principles of Managerial Finance 13th Edition. Boston: Prentice Hall.

10. Haron, S., \& Azmi, W. N. (2009). Islamic finance and banking system philosophies, principles \& practices. Selangor: The Mc Graw-Hill Companies.

11. Hoflich, P. (2011). Bank at risk: global best practices in an age of turbulance. United Kingdom: John Wiley \& Sons.

12. Islam (2017). Factors Affecting Liquidity Position of Islamic Bank. City University Research Journal AIC Malaysia. 27-36.

13. Ismal, R. (2010). Strengthening and Improving the Liquidity Management in Islamic Banking. Humanomics. 26(1): 18-35. Emerald Group Publishing Limited. DOI 10.1108/08288661011024977.

14. Kasmir. (2008). Analisis laporan keuangan. Jakarta (ID): Rajagrafindo Persada.

15. Kuncoro, M, \& Suhardjono. (2011). Manajemen perbankan teori and aplikasi. Yogyakarta: BPFE.

16. Latumaerissa, JR. 1999. Mengenal aspek-aspek operasi bank umum. Jakarta (ID): Bumi Aksara.

17. Muljono, T. P. (1999). Analisa Laporan Keuangan untuk Perbankan. Jakarta: Djambatan.

18. [OJK] Otoritas Jasa Keuangan. (2014). SEOJK No. 10/SEOJK.03/2014 tanggal 11 Juni 2014 tentang Penilaian Tingkat Kesehatan Bank Umum Syariah and Unit Usaha Syariah.

19. Soprano, A. A. (2015). Liquidity management a funding risk handbook. United Kingdom: John Wiley \& Sons Ltd.

20. Wuryandani, G., Ginting, R., Iskandar, D., \& Sitompul, Z. (2014). Pengelolaan dana and likuiditas bank. Buletin Ekonomi and Perbankan. Jakarta: Bank Indonesia. 